



ISSN 2278-0211 (Online)

\section{Pre-service Economics Teachers' Self-Efficacy Beliefs in Teaching Economics}

Kaku, Dominic Winston
M.Phil. Candidate, Department of Business and Social Sciences Education,
University of Cape Coast, Ghana
Arthur, Francis
M.Phil. Candidate, Department of Business and Social Sciences Education,
University of Cape Coast, Ghana

\begin{abstract}
:
This study examined Pre-service Economics teachers' self-efficacy beliefs in teaching Economics. The study employed the descriptive cross-sectional survey design and used census method to involve all 54 level 400 Bachelor of Education (Social Sciences) Economics major students in the University of Cape Coast. The Teacher Sense of Efficacy Scale was used for data collection. The data were analyzed using mean and standard deviation. A reliability coefficient of .940 was obtained. The results of the study revealed that Pre-service Economics teachers had a sense of self-efficacy beliefs in student engagement, instructional strategies and classroom management. It was recommended that the Economics education lecturers in the Department of Business and Social Sciences Education should continue to provide quality instructional delivery to student-teachers.
\end{abstract}

Keywords: Beliefs, efficacy, pre-service, self-efficacy, economics teachers

\section{Introduction}

The beliefs that an individual cherishes ultimately determines his or her life's decisions. On regularly basis, teachers' beliefs relating to their instructional abilities determine how they make decisions, comport themselves and manage their classroom milieu (Pajares, 1992). How teachers portray teaching is affected by these ideas, attitudes and notions about their abilities. Ng, Nicholas and Alan (2010) opined that this conception essentially determines their efficacy in classroom teaching.

According to Bandura (1997), perceived self-efficacy refers to belief in one's agentive capabilities that one can produce given levels of attainment. A self-efficacy assessment, therefore, includes both an affirmation of a capability level and the strength of that belief. The teacher self-efficacy is a multifaceted of beliefs that instructors or teachers embrace about their own worth and effectiveness based on their classroom instructional management skills (Romi \& Leyser, 2006). Teacher efficacy is a teacher's conviction or belief in his personal worth with regards to his teaching ability emerging from a sense of self-adequacy and personal understanding (Batool, Arif \& Parveen, 2012).

Tschannen-Moran and Woolfolk-Hoy (2001) developed the Teacher Sense of Efficacy Scale (TSES).The TSES comprised of 24 items with three sub-scales, specifically, efficacy for student engagement (SE), instructional strategies (IS) and classroom management (CM).Student engagement efficacy captures teachers' beliefs that they can effectively encourage students, involve parents, and help students value learning (Blazevski, 2006). Instructional strategies efficacy refers to teachers' beliefs that they can perform such instructional tasks as adapting content to student needs, questioning students, and assessing student learning (Tschannen-Moran \& Hoy, 2001). Classroom management efficacy represents teachers' self-efficacy for responding to disruptive behavior, monitoring work, and establishing norms and routines (Emmer \& Hickman, 1991). Wong and Wong (2009) defined classroom management as teacher's capability to keep order in the classroom, engage students in learning and elicit students' cooperation all activities in the learning environment.

The TSES suggests that in measuring teachers' self-efficacy beliefs, one need to focus on these three dimensions: students' engagement, instructional strategies and classroom management. Since the ability of teachers to organize the classroom and manage the behaviour of the students, engage students and deploy better instructional strategies in the teaching and learning milieu, is critical to achieving positive educational outcomes, it is imperative to ascertain the selfefficacy beliefs of Pre-service Economics teachers' self-efficacy beliefs in teaching Economics.

\subsection{Review of Related Literature}

In Germany, Holzberger, Philipp, and Kunter (2012) conducted a study to ascertain the relationship between teachers' self-efficacy and instruction. The results of the study indicated that teachers with higher self-efficacy beliefs showed higher instructional quality. This finding parallels that of Klassen and Chiu (2010) who posited that teachers have 
high self-efficacy beliefs in instructional strategies. Again, Shaukat and Iqbal (2012) concluded that teachers were efficacious in their instructional strategies.

Page, Pendergraft and Wilson (2014) conducted a study to investigate if teachers at urban, rural and suburban elementary schools differ significantly in their sense of self-efficacy. The findings of their results indicated that the teachers at the urban elementary school displayed significantly lower scores on the TSES than did the teachers at suburban and rural schools.

In South Africa, Suriamurthee and Kudayja (2010) conducted a study to investigate high-school Economics teachers' beliefs about the teaching of Economics. It was found that Economics teachers perceive their role as important in the learning process. Also, male teachers in particular see the teacher as the dominant influence on learner performance, and are more confident than female teachers of their knowledge and teaching abilities.

Boateng and Sekyere (2018) conducted a study to explore in-service teachers' self-efficacy in the kindergarten classrooms in Ghana. The study used kindergarten teachers selected from both public and private kindergarten schools. Results of the study indicated that kindergarten teachers in the Kumasi Metropolis of Ghana have high efficacy beliefs in pupils' engagement. The findings of this study are consistent with Bakar, Mohammed and Zakaria's (2012) study on Turkish and Malaysian pre-service teachers respectively. Again, a similar result was reported by Abroampa, Rotimi and Asante (2017) who found that early childhood pre-service teachers in Ghanaian teacher education universities have high self-efficacy.

In relation to classroom management, Cobbold and Boateng (2016) investigated kindergarten teachers' sense of efficacy in classroom management in Ghana. The findings of their study indicated that kindergarten teachers exhibited a high sense of efficacy in classroom management. In a different context, Poulou (2007) and Guo, Justice, Sawyer and Tompkins (2011) observed that preschool teachers' have high sense of self-efficacy in classroom management. Classroom management is a crucial component of pre-service teacher training and in-service teacher behaviour (Emmer \& Stough, 2001)

\subsection{Statement of the Problem}

In Singapore, $\mathrm{Ng}$ (2011) investigated female primary teachers' self-efficacy for teaching Science. The thrust of the study was to measure the Self-efficacy of Singapore female primary Science teachers. The findings of study revealed that some of the female Science teachers were highly efficacious. Yet the study failed to measure their efficacy beliefs on student engagement, instructional strategies and classroom management.

In Ghana, Boateng, Arhin, Owusu-Sekyere, Kotor and Adarkwah (2019) conducted a study to explore teaching efficacy beliefs of Ghanaian basic school teachers and their subject specialization. The results of the study showed that inservice teachers have a high sense of personal teaching efficacy. However, the study involved only basic school in-service teachers; the study could have also involved senior high school (SHS) Pre-service teachers. Likewise, studies have surveyed Ghanaian Pre-service teachers' self-efficacy beliefs; the focus has been on early childhood Pre-service teachers' self-efficacy (Abroampa, Rotimi \& Asante, 2017)

Bekoe, Kankam, Ayaaba, Eshun and Bodorh (2015) also conducted a study on the self-efficacy beliefs of Preservice teachers in colleges of education. It appears no study have been done on the self-efficacy beliefs of Pre-service teachers in the Universities in Ghana, specifically, Bachelor of Education (Social Sciences) Economics major students. The current study seeks to ascertain Pre-service Economics teachers' self-efficacy beliefs in teaching Economics.

Again, some studies on teacher efficacy have focused on pre-service teachers, novice teachers, elementary and secondary school teachers (Woolfolk \& Hoy, 2001; Ozder, 2011). It seems most of the studies have not focussed on Preservice Economics teachers' self-efficacy beliefs in student engagement, instructional strategies and classroom management. A few available studies in Ghana focused on kindergarten teachers' efficacy for instructional practices (Cobbold \& Boateng, 2015) and efficacy for classroom management practices (Cobbold \& Boateng, 2016). This current study is an attempt to fill this gap left by previous studies. This study departs from previous ones in the sense that it exclusively verifies Pre-service Economics teachers' self-efficacy beliefs in teaching Economics.

\subsection{Purpose of the Study}

The purpose of the study was to examine Pre-service Economics teachers' Self-efficacy beliefs in teaching Economics. In specific terms, the study is intended to:

- Ascertain Pre-service Economics teachers' levels of self-efficacy beliefs in student engagement.

- Determine Pre-service Economics teachers' levels of self-efficacy beliefs in instructional strategies.

- Find out Pre-service Economics teachers' levels of self-efficacy beliefs in classroom management.

\subsection{Research Questions}

- What are Pre-service economics teachers' levels of self-efficacy beliefs in student engagement?

- What are Pre-service economics teachers' levels of self-efficacy beliefs in instructional strategies?

- What are Pre-service economics teachers' levels of self-efficacy beliefs in classroom management?

\section{Methodology}

\subsection{Research Design}

The descriptive cross-sectional survey design was used for the study. According to Cohen, Manion and Morrison (2018) such research design often considers individuals, groups, institutions, methods and materials in order to describe, 
compare, contrast, classify, analyse and interpret the entities and the event that constitute their various fields of inquiry. The study sought to analyse the self-efficacy beliefs of Pre-service Economics teachers; this research design was found appropriate. The high degree of representativeness and the ease with which the researchers can obtain the views of participants using descriptive research design makes it an ideal choice (Polit \& Beck, 2004).

\subsection{Population}

The population of the study comprised all level 400Bachelor of Education (Social Sciences) Economics major students of 2019/2020 academic yearat the University of Cape Coast (UCC).

Level 400 Bachelor of Education (Social Sciences) Economics major students of 2019/2020 academic year at the University of Cape Coast.

\subsection{Census Method}

The census method was employed in the study to select all level 400 Bachelor of Education (Social Sciences) Economics major students of 2019/2020 academic year at the University of Cape Coast.Unlike Business students, Economics students are quite limited in number. The census method was found suitable for the purpose of the study to involve all level 400 Bachelor of Education (Social Sciences) Economics major students. In all, the total number of Preservice Economics teachers used for the study was 54 . The census method was used based on the recommendation of Gall, Borg and Gall (1996) that it gives better judgment.

\subsection{Research Instrument}

In this current study, the Teacher Sense of Efficacy Scale (long form) developed by Tschannen-Moran and Woolfolk-Hoy (2001) was adapted for the data collection. The TSES comprises of 24 items with three sub-scales, specifically, efficacy for student engagement (SE), instructional strategies (IS) and classroom management (CM). The 9point scale in the original version was adapted to a five-point Likert scale, that is, 1 (Not at all), 2 (Very little), 3 (Some influence), 4 (Quite a bit) and 5 (A great deal). Higher score on this scale likened to greater self-efficacy beliefs.The Cronbachalpha reliability coefficient of the instrument was .940. Ideally, the Cronbach alpha coefficient of a scale should be above 7 (DeVellis, 2012), this suggests that the degree of internal consistency of the instrument is high (.940). Again, according to Fraenkel and Wallen (2000), a reliability coefficient of 0.78 is acceptable, hence the instrument used for the study is reliable.

\subsection{Procedure for Data Collection}

Before administering the instrument, the researcher visited the lecturer whose class was used in reaching the respondents with a letter of introduction from the Head of Department, Department of Business and Social Sciences Education (DoBSSE), of the University of Cape Coast.The questionnaire was administered by the researchers. It is ethical in research to assure respondents of their confidentiality and anonymity; hence the questionnaire was accompanied with a cover letter to this effect and to crave their maximum co-operation. The respondents were given $15-20$ minutes to complete the questionnaire. After collecting the filled questionnaire, each completed instrument was quickly reviewed for absolute completeness.

\subsection{Data Analysis Procedure}

Data collected were coded and refined with the help of SPSS (version 24). Research question one to three were analysed using means and standard deviations.

\section{Presentation of Results}

- Research Question 1: What are Pre-service economics teachers' levels of self-efficacy beliefs in student engagement?

This research question sought to find out Pre-service economics teachers' self-efficacy beliefs in student engagement.

Tables 1 to 3 present the self-efficacy beliefs of Pre-service Economics teachers. These are: student engagement, instructional strategies and classroom management. The mean ranges for the responses were given as: Not at all $=1$, Very little $=2$, Some influence $=3$, Quite a bit $=4$ and A great deal $=5$. The responses were analysed using means and standard deviations with cut-off point values as $(0-1.4=$ Not at all, $1.5-2.4=$ Very little, $2.5-3.4=$ Some influence, $3.5-4.4=$ Quite a bit, $4.5-5$ = A great deal).

Table 1 describes the responses from Pre-service Economics teachers' self-efficacy beliefs based on student engagement. 


\begin{tabular}{|c|c|c|c|}
\hline S/N & Statement & Mean & SD \\
\hline 1 & Get through to the most difficult students & 3.61 & .87 \\
\hline 2 & Help your students think critically & 3.96 & .91 \\
\hline 3 & Motivate students who show low interest in school work & 4.07 & .94 \\
\hline 4 & Get students to believe they can do well in school work & 4.24 & .97 \\
\hline 5 & Help your students value learning & 4.22 & .90 \\
\hline 6 & Foster student creativity & 3.88 & .71 \\
\hline 7 & Understanding of a student who is failing & 4.07 & .82 \\
\hline 8 & Assist families in helping their children do well in school & 3.57 & .94 \\
\hline & GrandMean/Average Standard Deviation & 3.95 & .88 \\
\hline
\end{tabular}

Table 1: Pre-service Economics Teachers Self-Efficacy Beliefs in Student Engagement

Source: Field Survey, 2020

In relation to student engagement, from Table 1, the average mean of 3.95 compared to the cut-off point of 3.5 4.4 for quite a bit, indicates that respondents believe themselves to be efficacious. The average standard deviation score $(\mathrm{SD}=.88)$ suggests that, Pre-service Economics teachers' responses to the items on this particular subscale were homogeneous.

As clearly shown in Table 1, the highest mean value recorded was ( $M=4.24, \mathrm{SD}=.97)$, and is in relation to the fact that teachers 'Get students to believe they can do well in school work'. This implies that a majority of the respondents believe that they are efficacious in getting students to believe they can do well in school work. However, 'assist families in helping their children do well in school' recorded the least mean value $(M=3.57)$ for this subscale.

On the whole, the Pre-service Economics teachers affirmed that they havea high sense of efficacy in student engagement. This is revealed in the result of an average mean of 3.95.

- Research Question 2: What are Pre-service economics teachers' levels of self-efficacy beliefs in instructional strategies?

This research question was used to find out Pre-service economics teachers' level of self-efficacy beliefs in instructional strategies.

Table 2 describes the responses from Pre-service Economics teachers' self-efficacy beliefs in instructional strategies. The Pre-service Economics teachers were offered with eight items to respond in terms of their self-efficacy beliefs in instructional strategies. The summary of the findings is indicated in Table 2.

\begin{tabular}{|c|c|c|c|}
\hline S/N & Statement & Mean & SD \\
\hline 1 & Respond to difficult questions from your students & 3.96 & .86 \\
\hline 2 & Gauge student comprehension of what you have taught & 3.98 & .96 \\
\hline 3 & Craft good questions for your students & 4.05 & .89 \\
\hline 4 & Adjust your lessons to the proper level for individual students & 3.98 & .81 \\
\hline 5 & Use a variety of assessment strategies & 4.12 & .95 \\
\hline 6 & Provide an alternative explanation oran example when students are confused & 4.12 & .91 \\
\hline 7 & Implement alternative strategies in your classroom & 3.88 & .69 \\
\hline 8 & Provide appropriate challenges for very capable students & 4.03 & .86 \\
\hline & Grand Mean/Average Standard Deviation & 4.01 & .86 \\
\hline
\end{tabular}

Table 2: Pre-service Economics Teachers Self-Efficacy Beliefs in Instructional Strategies Source: Field Survey, 2020

It can be seen from Table 2 that the highest mean value recorded was on both statements that Pre-service teachers can 'use a variety of assessment strategies' and 'provide an alternative explanation or an example when students are confused' $(\mathrm{M}=4.12, \mathrm{SD}=.95 ; \mathrm{M}=4.12$, $\mathrm{SD}=.91)$ respectively. On the other hand, the lowest mean value was on the statement that teachers' can implement alternative strategies in their classroom $(\mathrm{M}=3.88$, $\mathrm{SD}=.69)$. Moreover, an average mean of 4.01 was recorded. This indicates that most of the respondents confirmed that they are efficacious when it comes to deploying instructional strategies in the classroom. An average standard deviation of .86 implies that the responses are scattered around the mean.

- Research Question 3: What are Pre-service economics teachers' levels of self-efficacy beliefs in classroom management?

The last research question was meant to ascertain Pre-service economics teachers' level of self-efficacy beliefs in classroom management.

Table 3 presents the results from the analysis of data provided by the respondents on Pre-service Economics teachers' self-efficacy beliefs in classroom management. 


\begin{tabular}{|c|c|c|c|}
\hline S/N & Statement & Mean & SD \\
\hline 1 & Control disruptive behaviour in the classroom & 4.12 & .84 \\
\hline 2 & Make your expectations clear about student behaviour & 3.90 & .95 \\
\hline 3 & Establish routines to keep activities running smoothly & 4.00 & .91 \\
\hline 4 & Get students to follow classroom rules & 4.05 & .89 \\
\hline 5 & Calm a student who is disruptive or noisy & 4.05 & .87 \\
\hline 6 & Establish a classroom management system with each group of students & 4.03 & .86 \\
\hline 7 & Keep a few problem students form ruining an entire lesson & 3.88 & .94 \\
\hline 8 & Respond to defiant students & 3.87 & 1.01 \\
\hline & Average Mean/Average Standard Deviation & 3.98 & .91 \\
\hline
\end{tabular}

Table 3: Pre-service Economics Teachers Self-Efficacy Beliefs in Classroom Management

Source: Field Survey, 2020

From Table 3, it can be observed that the highest mean value recorded was on the statement that teachers can control disruptive behaviour in the classroom $(\mathrm{M}=4.12, \mathrm{SD}=.84)$ while the lowest mean value was the on the statement 'respond to defiant students' $(M=3.87, \mathrm{SD}=1.01)$. Furthermore, an average mean of 3.98 was recorded. This implies that most of the respondents believe that they have a high sense of efficacy in classroom management. The average standard deviation of .91 suggests that the responses are scattered around the mean.

In order to ascertain which of the subscales that Pre-service Economics teachers were more efficacious, the three subscales were ranked and this presented in Table 4.

Table 4 presents a summary of the ranking of Pre-service Economics teachers' self-efficacy beliefs.

\begin{tabular}{|c|c|c|c|}
\hline Domain of Teachers' Self-Efficacy Beliefs & Mean & SD & Rank \\
\hline Self-Efficacy in Student Engagement & 3.95 & .88 & $\mathbf{3}^{\text {rd }}$ \\
\hline Self-Efficacy in Instructional Strategies & 4.01 & .86 & $\mathbf{1}^{\text {st }}$ \\
\hline Self-Efficacy in Classroom Management & 3.98 & .91 & $\mathbf{2}^{\text {nd }}$ \\
\hline Grand Mean/Average Standard Deviation & 3.98 & .88 & \\
\hline
\end{tabular}

Table 4: Ranking of Pre-service Economics Teachers' Self-Efficacy Beliefs

Source: Field Survey, 2020

Table 4 shows the mean and standard deviation values for student engagement $(M=3.95, S D=.88)$, instructional strategy $(M=4.01, S D=.86)$ and classroom management $(M=3.98, S D=.91)$. The results from Table 4 indicates that Preservice Economics teachers reported a high sense of efficacy in instructional strategies $(M=4.01, S D=.86)$ and it was ranked 1st.The second (2nd) on the rank was classroom management ( $M=3.98, S D=.91)$ and the third (3rd) was student engagement $(\mathrm{M}=3.95, \mathrm{SD}=.88)$.

In general, a grand mean value of 3.98 (approximately 4) was recorded for the three subscales. This reveals that Pre-service Economics teachers largely believe themselves to be efficacious.

\section{Discussion of Results}

The first research question of this study was to ascertain Pre-service Economics teachers' self-efficacy beliefs in student engagement. The findings of the study showed that Pre-service Economics teachers have a high sense of efficacy in student engagement. The findings of the study validate that of Boateng and Sekyere (2018) who posited that kindergarten teachers in high efficacy beliefs in pupils' engagement. The finding of the study implies that Pre-service Economics teachers are highly confident in their ability to help Economics students become and remain involved, devoted, or inspired for learning.

Research question two sought to determine Pre-service Economics teachers' self-efficacy beliefs in instructional strategies. The result of the study indicated that Pre-service Economics teachers perceived themselves to be efficacious in instructional strategies. The finding of the study lends credence to that of Klassen and Chiu (2010) who concluded that teachers have high self-efficacy belief in instructional strategies. A similar result was reported by Shaukat and Iqbal (2012) who asserted that teachers were efficacious in their instructional strategies. This finding of the study suggests that Preservice Economics teachers perceived themselves to be efficacious when it comes to deploying instructional strategies in the classroom.

The third research question was intended to find out Pre-service Economics teachers' self-efficacy beliefs in classroom management. The findings of the study revealed that Pre-service Economics teachers have a high sense of efficacy in classroom management. This finding of the study corroborates that of Cobbold and Boateng (2016) who asserted that kindergarten teachers exhibited a high sense of efficacy in classroom management. Again, the result is in line with the findings of Poulou (2007) and Guo, Justice, Sawyer and Tompkins (2011) who reported that preschool teachers' have high sense of self-efficacy in classroom management. The result of the study implies that Pre-service Economics teachers can assuredly establish and implement courses of action required to maintain classroom order.

The overall findings of the study revealed that Pre-service Economics teachers have a high sense of self-efficacy beliefs in teaching Economics. It can be inferred from the findings of the study that, the Pre-service Economics teacher education programme is effective in the delivery of the following aspects: student's engagement, instructional strategies and classroom management. This implication confirmed the claims of Yidana and Quartey (2017) that the Pre-service 
Economics teacher education programme has strength in the delivery of general pedagogy, instructional process competencies, classroom management etc.

\section{Conclusion and Recommendations}

The study was meant to ascertain the self-efficacy beliefs of Pre-service Economics teachers in teaching Economics. The findings of the study revealed that Pre-service Economics teachers have high sense of self-efficacy beliefs in student engagement, instructional strategies and classroom management. The fact that Pre-service Economics teachers' sense of self-efficacy beliefs were found to be fairly high implied that they had a solid conviction that they had adequate knowledge and skills of effective classroom instructional practices with regards to student's engagement, instructional strategies and classroom management. It is recommended that the Economics education lecturers in the Department of Business and Social Sciences Education should continue to provide quality instructional delivery to student-teachers. Again, future research studies should focus on longitudinal study of Economics teachers' self-efficacy beliefs in teaching Economics in the various SHS's in Ghana.

\section{References}

i. Abroampa, K.W., Rotimi, O. W., \& Asante, N. J. (2017). Sources of efficacy as predictors of early childhood Preservice teachers' self-efficacy in Ghanaian teacher universities. Asia-Pacific Journal of Research in Early Childhood Education, 11(12), 67-84.

ii. Bakar, A. R., Mohammed, S., \& Zakaria, N. S. (2012). They are trained to teach but how confident are they? A study of student teachers' sense of efficacy. Journal of Social Sciences, 8(4), 497-504.

iii. Boateng, P., Arhin, A. K., Owusu-Sekyere, F., Kortor, A., \& Adarkwah, S. N. (2019). Teaching efficacy beliefs of Ghanaian basic school teachers and their subject specializations. African Journal of Teacher Education, 8, 281-298.

iv. Cobbold, C., \& Boateng, P. (2015). Exploring the instructional practices efficacy beliefs of kindergarten teachers in the Kumasi Metropolis of Ghana. Journal of Developing Country Studies, 5(6), 174-187.

v. Cobbold, C., \& Boateng, P. (2016). How confident are kindergarten teachers in their ability to keep order in the classroom? A study of teacher efficacy in classroom management. Journal of Education and Practice, 7(36), 181190.

vi. Cohen, L., Manion, L., \& Morrison, K. (2018). Research methods in education (8th ed.). New York: Routledge

vii. DeVellis, R. F. (2012). Scale development: Theory and applications (3rd ed). Thousand Oaks, California: Sage.

viii. Emmer, E. T., \& Stough, L. M. (2001). Classroom management: A critical part of educational psychology, with implications for teacher education. Educational Psychologist, 36(2), 102-112.

ix. Fraenkel, J. R., \& Wallen, N. E. (2000). How to design and evaluate research in education (4th ed). USA: McGrawHill Companies, Inc.

x. Gall, M. D., Borg, W. R., \& Gall, J. P. (1996). Educational research: An introduction (6th ed.). Longman Publishing.

xi. Guo, Y., Justice, L. M., Sawyer, B., \& Tompkins, V. (2011). Exploring factors relating to preschool teachers' selfefficacy. Teacher Education, 27, 961-968.

xii. Holzberger, D., Philip, A., \& Kunter, M. (2012). How teachers' self-efficacy is related to instructional quality: A longitudinal analysis. Journal of Educational Psychology, 105(3). 774-786.

xiii. Klassen, R., \& Chiu, M. (2010). Effects on teachers' self-efficacy and job satisfaction: Teacher gender, years of experience and job stress. Journal of Educational Psychology, 102, 741-756.

xiv. Ng, W., Nicholas, H., \&, Alan, W. (2010). School experience influences on pre-service teachers' evolving beliefs about effective teaching. Teaching and Teacher Education, 26, 278-289.

xv. Ng, Wee-Loon. (2011). A study of Singapore female primary teachers' self-efficacy for teaching Science. Doctoral thesis, Durham University. Available at Durham E-Theses Online: http://etheses.dur.ac.uk/606/

xvi. Ozder, H. (2011). Self-Efficacy beliefs of Novice teachers and their performance in the classroom. Australian Journal of Teacher Education, 36(5).

xvii. Page, S. C., Pendergraft, B., \& Wilson, J. (2014). Examining elementary teachers' sense of efficacy in three settings in the Southeast. Journal of Inquiry and Action in Education, 5(3), 2014.

xviii. Pajares, F. (1992). Teachers' beliefs and educational research: Cleaning up a messy construct. Review of Educational Research, 62, 307-332.

xix. Polit, D. F., \& Beck, C. T. (2004). Nursing research. Principles and methods. Philadelphia: Lippincott Williams \& Wilkins

xx. Poulou, M. (2007). Personal teaching efficacy and its sources: Student teachers' perceptions. Educational Psychology, 27(2), 191-218.

xxi. Romi, S., \&Leyser, Y. (2006). Exploring inclusion pre-service training needs: A study of variables associated with attitudes and self-efficacy beliefs. European Journal of Special Needs Education, 21(1), 85-105.

xxii. Ryan, A. M., Kuusinen, C. M., \& Bedoya-Skoog, A. (2015). Managing peer relations: A dimension of teacher selfefficacy that varies between elementary and middle school teachers and is associated with observed classroom quality. Contemporary Educational Psychology, 41, 147-156.

xxiii. Shaukat, S., \& Iqbal, H. M. (2012). Teacher self-efficacy as a function of student engagement, instructional strategies and classroom management. Pakistan Journal of Social and Clinical Psychology, 10(2), 82-85.

xxiv. Suriamurthee, M. M., \& Kudayja, P. (2010). Teacher efficacy: An investigation of Economics teachers. Africa Education Review, 7(2), 376-401. 
xxv. Tschannen-Moran, M., \& Woolfolk Hoy, A. (2001). Teacher efficacy: Capturing an elusive construct. Teaching and Teacher Education, 17, 783-805.

xxvi. Wong, H., \& Wong, R. (2009). The first days of school: How to become an effective classroom manager. Mountain View, CA: Harry K. Wong Publications.

xxvii. Yidana, M. B., \& Quartey, N. (2017). Effectiveness of pre-service Economics teacher education programme: Perspectives of university Economics teacher trainees. Journal of Educational Management, 4(3), 65-85. 